1 Tracing subarctic Pacific water masses with benthic foraminiferal stable isotopes during the LGM and late Pleistocene

Mea S. Cook ${ }^{1 *}$, A. Christina Ravelo ${ }^{2}$, Alan Mix ${ }^{3}$, Ian M. Nesbitt ${ }^{1,4}$ and Nari V. Miller ${ }^{1,5}$

${ }^{1}$ Geosciences Department, Williams College, 947 Main Street, Williamstown, MA 01267

${ }^{2}$ Ocean Sciences Department, University of California, 1156 High Street, Santa Cruz, CA 95064

${ }^{3}$ College of Earth, Ocean and Atmospheric Sciences, Oregon State University, Corvallis, OR 97331

${ }^{4}$ Now at e4 Sciences, 27 Glen Road, Sandy Hook, CT 06482

${ }^{5}$ Now at School for Earth and Space Exploration, Arizona State University, Tempe, AZ 85287

*Corresponding author. Email address: Mea.S.Cook@williams.edu

Keywords: Paleoclimate, Bering Sea, oxygen isotope stratigraphy, Pleistocene, ocean circulation

Submitted to Deep Sea Research II on 11/19/13

17 Revision submitted on 09/02/15

18 Final version submitted on 11/20/15

\title{
ABSTRACT
}

22 As the largest ocean basin, the Pacific helps to set the global climate state, since its circulation

23 affects mean ocean properties, air-sea partitioning of carbon dioxide, and the distribution of

24 global oceanic poleward heat transport. There is evidence that during the Last Glacial Maximum

25 (LGM) the subarctic Pacific contained a better-ventilated, relatively fresh intermediate water

26 mass above $\sim 2000 \mathrm{~m}$ that may have formed locally. The source and spatial extent of this water

27 mass is not known, nor do we know how formation of this water mass varied during Pleistocene

28 glaciations with different orbital and ice sheet boundary conditions. Here we present a $0.5 \mathrm{My}$

29 multi-species benthic stable isotope record from Site U1345 (1008 m) on the northern Bering

30 slope and a 1.0 My record from U1339 (1868 m) from the Umnak Plateau in the southeastern

31 basin. We find that the relatively well-ventilated low- $\delta{ }^{18} \mathrm{O}$ intermediate water reaches $1000 \mathrm{~m}$ in

32 the Bering Sea during MIS2, but that the hydrographic divide between this water mass and

33 poorly-ventilated deep water was shallower than $1000 \mathrm{~m}$ for earlier glaciations. We also compare 
34 Bering Sea piston core and IODP Expedition 323 Uvigerina data from the Holocene and LGM

35 with the modern hydrography, and to previously published profiles from the Okhotsk Sea and

36 Emperor Seamounts. We find that the carbon and oxygen stable isotope signatures of well-

37 ventilated water in the Bering and Okhotsk Seas are distinct, suggesting that there may have been

38 intermediate water formation in both basins during the LGM.

INTRODUCTION

41 The Pacific contains 50\% of the ocean volume (Eakins and Sharman, 2010) and is the largest

42 reservoir of deep water and carbon dioxide in the global ocean. The Pacific circulation state

43 therefore plays a large role in setting the properties of mean ocean water and air-sea partitioning

44 of carbon dioxide. Despite its size, the contribution of the Pacific to the modern global heat

45 transport is relatively small. The heat transport at mid-latitudes associated with North Pacific

46 Intermediate Water (NPIW) ventilation is only 0.1 PW, compared to $0.85 \mathrm{PW}$ associated with

47 the Atlantic Meridional Overturning Circulation (AMOC) (Talley, 2003).

49 Deep water does not form in the subarctic North Pacific today because of the low salinity of

50 surface water. This low salinity results from limited exchange between the subtropical and

51 subpolar gyres as well as an excess of precipitation over evaporation (Emile-Geay et al., 2003;

52 Warren, 1983), and net freshwater flux from the Atlantic to the Pacific across Central America

53 (Leduc et al., 2007). The deep Pacific is fairly homogeneous deeper than $1000 \mathrm{~m}$, with a

54 maximum in $\Delta^{14} \mathrm{C}$ at about 2000 m marking the depth of the oldest Pacific Deep Water (PDW)

55 (Key et al., 2002). 
57 The history of Pacific circulation is poorly understood and consequently, so is its role in glacial-

58 interglacial climate change processes, including sequestration and outgassing of carbon dioxide,

59 heat and freshwater transport, and moisture supply to the atmosphere. In the past, Pacific

60 circulation appears to have been different than today. During the Last Glacial Maximum (LGM),

61 profiles of Cibicidoides $\delta^{13} \mathrm{C}$ from the western Pacific (Duplessy et al., 1988; Keigwin, 1998;

62 Herguera et al., 1992; Matsumoto et al., 2002) show that there is a hydrographic divide at around

$632000 \mathrm{~m}$ between an apparently nutrient-depleted well-ventilated water above, and a poorly-

64 ventilated deep water below. The $\delta^{13} \mathrm{C}$ and $\delta^{18} \mathrm{O}$ data do not constrain the source of this upper

65 water mass, it may have originated locally, it may be Glacial North Atlantic Intermediate Water

66 (GNAIW) transported via the Southern Ocean, or it could be a mixture of water of both Pacific

67 and Atlantic origin (Matsumoto et al., 2002). Because of unknown changes in local surface

68 reservoir age in the past, benthic-planktonic radiocarbon measurements from this water mass are

69 ambiguous as to whether it was better ventilated than the modern ocean (Keigwin, 2002).

71 Today, NPIW ventilates during winter sea-ice formation in the Okhotsk Sea (Shcherbina et al.,

72 2003). The $26.80 \sigma_{\theta}$ isopycnal surface at the core of NPIW is very shallow in Gulf of Alaska

73 (MacDonald et al., 2001), suggesting that NPIW may episodically form there as well (Van Scoy

74 et al., 1991). A radiolarian associated with cold, well-ventilated water in the Okhotsk Sea today

75 is most abundant in the Bering Sea during the LGM (Ohkushi et al., 2003; Tanaka and Takahashi,

76 2005), suggesting that the Bering Sea may have been the source of intermediate water at that

77 time. The $\varepsilon N d$ measured in bulk-sediment leachates of Fe-Mn oxyhydroxides in the southern

78 Bering Sea is more radiogenic during glaciations, which is also consistent with a North Pacific

79 source of well-ventilated intermediate water (Horikawa et al., 2010). Where does this glacial 
80 water mass form? How did it evolve during glacial initiation? How does its volume and mode of

81 formation vary between glacial cycles?

83 The Integrated Ocean Drilling Program Expedition 323 to the Bering Sea recovered sediment

84 spanning the Pleistocene and Pliocene, allowing systematic investigation of the pattern of

85 glacial-interglacial climate and circulation changes through time as orbital boundary conditions

86 varied. Site U1342 from 830 m from Bowers Ridge in the south-central Bering Sea shows that

87 Pleistocene glaciations are characterized by a relatively high- $\delta^{13} \mathrm{C}$, low- $\delta^{18} \mathrm{O}$ water mass that

88 may have originated as brine from sea-ice formation in the Bering Sea (Knudson and Ravelo,

89 2015). In this paper, we present benthic stable isotope stratigraphies from Sites U1345 (1008 m,

$\left.9060.15^{\circ} \mathrm{N}, 179.50^{\circ} \mathrm{W}\right)$ on the northern continental slope and $\mathrm{U} 1339\left(1868 \mathrm{~m}, 54.67^{\circ} \mathrm{N}, 169.98^{\circ} \mathrm{W}\right)$

91 from the southeastern Bering Sea. With these cores, we can trace the depth of the hydrographic

92 divide during glaciations of the late Pleistocene. We also compare a compilation of benthic

93 foraminiferal stable isotope data from the Bering Sea LGM to published data from the Okhotsk

94 Sea.

95

96 METHODS

97 In U1339 and U1345, we collected two 2-cm half round samples per core section from the

98 primary splice (Takahashi et al., 2011), resulting in a sampling interval of $\sim 75 \mathrm{~cm}$. In U1345, we

99 took additional samples in intervals where lower foraminiferal abundance or preservation

100 resulted in gaps in the stable isotope stratigraphy. We freeze-dried the samples, washed them

101 through a $63 \mu \mathrm{m}$ sieve with distilled water, then oven-dried them at $50^{\circ} \mathrm{C}$. From the $>150 \mu \mathrm{m}$

102 size fraction, we picked the benthic foraminiferal species Uvigerina peregrina, U. senticosa and 
Elphidium cf. batialis in U1339, and U. peregrina, Nonionella labradorica and Globobulimina

104 affinis in U1345.

105

106 For each sample, we cleaned 3 tests of each benthic species by sonicating in methanol and

107 deionized water. We measured the U1345 samples and the upper $50 \mathrm{~m}$ (CCSF-A) of U1339 at

108 the Oregon State University College of Earth, Oceanic and Atmospheric Sciences Stable Isotope

109 Mass Spectrometer Facility using a Thermo-Finnigan MAT-252 mass spectrometer with a Kiel

110 III carbonate device, using NBS-19 and Wiley (internal calcite lab standard) to correct the data

111 relative to VPDB, with an analytical precision of $0.05 \%$ for $\delta^{18} \mathrm{O}$ and $0.03 \%$ for $\delta^{13} \mathrm{C}$. We

112 measured the remaining U1339 samples at the University of California, Santa Cruz, Stable

113 Isotope Laboratory using a Fisons Prism III mass spectrometer with a common acid bath, and a

114 Thermo-Finnigan MAT-253 mass spectrometer with a Kiel IV carbonate device, using NBS-19

115 and Carrera Marble (internal calcite lab standard) to correct the data relative to VPDB, with an

116 analytical precision of $0.08 \%$ for $\delta^{18} \mathrm{O}$ and $0.05 \%$ for $\delta^{13} \mathrm{C}$.

118 In order to compare the sediment data to modern hydrography, we present water column and

119 multicoretop data from samples collected in July, 2002, during HLY02-02 (Figure 1). See

120 (Lehmann et al., 2005) for hydrostation water collection methods. The $\delta^{13} \mathrm{C}$ of dissolved

121 inorganic carbon (DIC) $\left(\delta^{13} \mathrm{C}_{\mathrm{DIC}}\right)$ was determined at the National Ocean Science Accelerator

122 Mass Spectrometer (NOSAMS) laboratory at Woods Hole Oceanographic Institution by

123 acidification and automated vacuum extraction of poisoned $\sim 500 \mathrm{~mL}$ waters samples, followed

124 by isotope ratio measurements on the NOSAMS VG-PRISM mass spectrometer (McNichol et al.,

125 1994). The standard deviation of replicate extractions and isotopic analyses was 0.04\%o ( $\mathrm{n}=14)$; 
$126 \delta^{13} \mathrm{C}$ values are reported relative to VPDB. The $\delta^{18} \mathrm{O}$ of water $\left(\delta^{18} \mathrm{O}_{w}\right)$ was determined in the

127 laboratory of D. Schrag (Harvard University) using a VG Optima mass spectrometer with a VG

128 Isoprep 18 automated shaker/equilibrator (Schrag et al., 2002). The standard deviation of

129 replicate $\delta^{18} \mathrm{O}$ analyses was $0.02 \%$ o $(\mathrm{n}=21) ; \delta^{18} \mathrm{O}_{\mathrm{w}}$ values are reported relative to VSMOW.

131 During HLY02-02, 10-cm-diameter multicorer subcores were sliced at $1 \mathrm{~cm}$ intervals, and

132 sediment samples were preserved at sea with a buffered seawater-formalin mixture (Corliss and

133 Emerson, 1990; McCorkle et al., 1997; McCorkle et al., 1990). In the lab, the 0-1 and 1-2 cm

134 samples were stained with Rose Bengal ( $1 \mathrm{~g} / \mathrm{L}$ final concentration) for at least 1 week, and

135 specimens with one or more chambers fully stained a bright pink were picked wet from the $>150$

$136 \mathrm{~mm}$ fraction for isotopic analysis. Between 4 and 6 Uvigerina, and 2 to 7 Cibicidoides were

137 analyzed on a Finnigan MAT253 mass spectrometer with a Kiel device at the Woods Hole

138 Oceanographic Institution Micropaleontology Stable Isotope Laboratory, using NBS-19 and

139 Carrara Marble (calcite internal lab standard) to correct the data relative to VPDB, with an

140 analytical precision of $0.07 \%$ for $\delta^{18} \mathrm{O}$ and $0.03 \%$ for $\delta^{13} \mathrm{C}$ (Ostermann and Curry, 2000).

142 We present the $\delta^{18} \mathrm{O}_{\mathrm{w}}$ profiles from all Bering Sea hydrocast stations in Figure 2a, and the CTD

$143 \mathrm{~T}$ and $\mathrm{S}$ in Figures $2 \mathrm{~b}$ and 2c. For comparison, we include the hydrocast data reported in

144 Keigwin (1998) from the Okhotsk Sea and near the Emperor Seamounts (see station locations in

145 Figure 1). In Figure 2d, we show the linear least-squares best-fit line between salinity and $\delta^{18} \mathrm{O}_{\mathrm{w}}$

146 for each region. We calculated the equilibrium $\delta^{18} \mathrm{O}$ of calcite $\left(\delta^{18} \mathrm{O}_{\mathrm{c}}\right)$ using the CTD T and S of

147 each hydrographic station, applying the regression in Figure $2 \mathrm{~d}$ to get $\delta^{18} \mathrm{O}_{\mathrm{w}}$. We used the

148 equation from Shackleton (1974): 


$$
T=16.9-4.0\left(\delta^{18} \mathrm{O}_{\mathrm{c}}-\delta^{18} \mathrm{O}_{\mathrm{w}}\right)
$$

150 where $\delta^{18} \mathrm{O}_{\mathrm{W}}$ and $\delta^{18} \mathrm{O}_{\mathrm{C}}$ are relative to VPDB, and $\mathrm{T}$ is in Celsius. We converted $\delta^{18} \mathrm{O}_{\mathrm{W}}$ from

151 VSMOW to VPDB with $\delta^{18} \mathrm{O}_{\mathrm{w}}(\mathrm{VPDB})=\delta^{18} \mathrm{O}_{\mathrm{w}}(\mathrm{VSMOW})-\mathbf{0 . 2 7}($ Coplen, 1988).

153 RESULTS

\section{Authigenic carbonates}

155 There are visible authigenic carbonate overgrowths on some samples in U1339, where the

156 foraminiferal tests are yellowish, which has been observed at many coring sites around the

157 Bering Sea (Cook et al., 2010; Takahashi et al., 2011; Rella et al., 2012; Asahi et al., in press,

158 this volume). These samples have low measured $\delta^{13} \mathrm{C}$ (Figure 3), which is a signature of

159 carbonates associated with anaerobic oxidation of methane (AOM), and is probably not a

160 primary signal recorded from pore water (Herguera et al., 2014). Porewater profiles show that

161 Mg-rich calcite is precipitating in the sulfate-methane transition zone (SMTZ), and that the

162 SMTZ is shallow, at 8-10 mbsf in U1339 and 6-7 mbsf in U1345 (Takahashi et al., 2011;

163 Wehermann et al., 2011). Though there are several types of authigenic carbonates found in

164 Bering Slope sediments, which form during successive stages of diagenesis, it's likely that the

165 carbonate coatings on foraminifera form during early diagenesis in the SMTZ associated with

166 AOM (Pierre et al., 2014). At sites at the Umnak Plateau, these coatings have been characterized

167 has having very low $\delta^{13} \mathrm{C}\left(-22\right.$ to $-24 \%$ ) and high $\delta^{18} \mathrm{O}(\sim 6.5 \%$ o) (Cook et al., 2011).

169 Since authigenic carbonates are not always visible on samples with anomalous stable isotopes,

170 we flagged samples where the Uvigerina and Nonionella $\delta^{13} \mathrm{C}$ were less than $-2.5 \%$, assuming

171 that such low $\delta^{13} \mathrm{C}$ from these shallow infaunal species is an artifact of authigenesis, making both 
172 the $\delta^{13} \mathrm{C}$ and $\delta^{18} \mathrm{O}$ measurements unreliable. The samples that failed this criterion were only in

173 U1339. These points are plotted with open circles in Figure 3 and 4 and are not shown in Figure

174 5. The scatter of flagged samples is consistent with their being a mixture of foraminiferal calcite 175 and authigenic carbonates (Figure 4a). If we assume the composition of the authigenic

176 carbonates is similar to those observed by Cook et al. (2011), the $\delta^{18} \mathrm{O}$ difference between

177 foraminiferal calcite and authigenic carbonates ( 3\%) is much smaller than the $\delta^{13} \mathrm{C}$ difference

178 ( 20\%) (Figure 4), so even if this filtering by $\delta^{13} \mathrm{C}$ does not capture all samples with authigenic

179 carbonate contamination, the influence on the $\delta^{18} \mathrm{O}$ values is probably relatively small. The

180 filtering does, however, clip the $\delta^{13} \mathrm{C}$ record, and it's possible that some $\delta^{13} \mathrm{C}$ data points remain 181 are biased by authigenic carbonates.

182

183 Species-species offsets

184 No one benthic species was present in all samples, so we assembled a multi-species composite $185 \delta^{18} \mathrm{O}$ record. For each sample where we measured multiple species, we plotted the anomaly in 186 the other species relative to U. peregrina (Figure 5), then calculated the mean and standard 187 deviation of the anomaly (Figure 5, Table 1) assuming that this vital effect is constant through 188 time. The species-species offsets we observe fall within the 1-sigma uncertainty of the offsets 189 observed by Asahi et al. (in press, this volume) for nearby site U1343, and as they note, are 190 consistent with previously published species-species offsets (McCorkle et al., 1997). The stable 191 isotope stratigraphy plotted in Figure 3a shows the $\delta^{18} \mathrm{O}$ measurements corrected for the species192 species offsets in Table 1.

193 
194 The $\delta^{13} \mathrm{C}$ of shallow infaunal benthic species are influenced by vital effects as well as differences

195 in depth habitat and the gradient in porewater $\delta^{13} \mathrm{C}$ (McCorkle et al., 1990; McCorkle et al.,

196 1997). We calculated the $\delta^{13} \mathrm{C}$ offset only between the related species $U$. peregrina and $U$.

197 senticosa (Figure 5c) in U1339 (Figure 5c, Table 1), and applied the correction in Figures 6-10.

198 To test whether the $\delta^{13} \mathrm{C}$ difference between these two species is influenced by changes in

199 productivity affecting porewater $\delta^{13} \mathrm{C}$ gradients, we plotted the $\delta^{13} \mathrm{C}$ difference with GRA

200 density in U1339 (Figure 4b) and found there is no relationship. The GRA density in U1339 is

201 driven by opal abundance, a proxy for productivity (Takahashi et al., 2011). In addition, though

202 the productivity increased between the LGM and Holocene in the Okhotsk Sea (Kohfeld and

203 Chase, 2011), the constant $\delta^{13} \mathrm{C}$ offset correction between Cibicioides and $U$. senticosa (Figure

204 8b, 8d) was sufficient for both time periods, and at a range of depths (1 to $4 \mathrm{~km}$ ) where organic

205 matter rain rate presumably also varied. These two lines of evidence suggest that Uvigerina $\delta^{13} \mathrm{C}$

206 may be relatively insensitive to variations in productivity.

207

208 Age model

209 We identified the Marine Isotope Stages in the stable isotope records by selecting depths at the

210 mid-point of transitions between glacials and interglacials in comparison to the global stack

211 (Lisiecki and Raymo, 2005) (Table 2). In U1339, we also used the GRA density as a guide to

212 selecting the depths of glacial terminations (Figure 3a), since they are usually associated with an

213 abrupt decrease in density (Takahashi et al., 2011). In U1345, the age model shows that the

214 relationship between magnetic susceptibility (MS) and glacial cycles is complex, but that

215 glaciations are generally associated with lows in MS, and interglacials with highs in MS (Figure 
216 3f). The U1339 sediment record extends 1.0 My to MIS23 and U1345 extends $\sim 0.5$ My to

217 MIS13.

218

219 Microfossil preservation was generally poorer in U1345 than the other sites and the lower

220 abundance of foraminifera in U1345 during deglaciations and peak interglacials mean that the

221 timing of the deglaciation is not well constrained for terminations 2, 4 and 5. For the same reason,

222 we do not capture the minimum $\delta^{18} \mathrm{O}$ from peak interglacial MIS 5 or the maximum $\delta^{18} \mathrm{O}$ from

223 MIS 6, and may not capture the minima in MIS 9 and 11. The estimated uncertainty in the

224 identification of stage boundaries in Table 2 varies depending on sample spacing during the

225 transitions. Because of unknown phase relationships between the global benthic $\delta^{18} \mathrm{O}$ stack, local

$226 \delta^{18} \mathrm{O}$, and in $\mathrm{U} 1339$ the presumably productivity-driven density changes, the uncertainty in the

227 age of stage boundaries is probably several thousand years.

228

\section{Downcore comparisons}

230 We compare the U1345 (1008 m) and U1339 (1868 m) composite $\delta^{18} \mathrm{O}$ records with the $U$.

231 peregrina $\delta^{18} \mathrm{O}$ record from U1342 (Figure 6) from $819 \mathrm{~m}$ on Bowers Ridge (Knudson and

232 Ravelo, 2015) and the global benthic $\delta^{18} \mathrm{O}$ stack (Lisiecki and Raymo, 2005). With the exception

233 of MIS22, the $\delta^{18} \mathrm{O}$ difference between the shallowest (U1342) and deepest (U1339) sites during

234 glaciations is larger than $0.3 \%$ (the modern $\delta^{18} \mathrm{O}_{\mathrm{c}}$ difference between these depths), with the

235 difference ranging from $0.4 \%$ to $0.8 \%$ (Figure 7 and Table 4 ). For the length of the record,

$236 \mathrm{U} 1345(1008 \mathrm{~m}) \delta^{18} \mathrm{O}$ falls between the two other sites, but is indistinguishable from U1339 for

237 MIS 8, 10 and 12. During MIS 2, U1345 $\delta^{18} \mathrm{O}$ is $0.4 \%$ lower than U1339. The glacial maximum 
$238 \delta^{18} \mathrm{O}$ for MIS 6 is not captured because of low sample resolution during the glacial so is not 239 included in Figure 7 or Table 4.

241 We plot the $U$. peregrina $\delta^{13} \mathrm{C}$ records from U1339, U1345 and U1342 with the Cibicidoides

$242 \delta^{13} \mathrm{C}$ record from ODP849 in the east equatorial Pacific (Mix et al., 1995), after applying a

$243+0.9 \%$ o correction to the Uvigerina data (Mix et al., 1995) (Figure 6). The minimum $\delta^{13} \mathrm{C}$ values

244 in U1339 may be clipped because of the filtering we did to eliminate samples affected by low-

$245 \delta^{13} \mathrm{C}$ authigenic carbonates. For this reason, and also since $U$. peregrina does not appear in each

246 sample, careful comparison of the downcore $\delta^{13} \mathrm{C}$ records between Bering Sea sites is not

247 possible. However, there does not appear to be a systematic offset between Bering Sea sites

248 during glacials or interglacials.

250 Modern and Holocene depth profiles

251 The modern water column profiles of $\delta^{18} \mathrm{O}_{\mathrm{C}}$ and $\delta^{13} \mathrm{C}_{\mathrm{DIC}}$ at Bering Sea and Emperor Seamounts 252 are similar in shape and amplitude at depths greater than $500 \mathrm{~m}$ (Figure 8). There is increasing $253 \delta^{18} \mathrm{O}_{\mathrm{C}}$ with depth below $500 \mathrm{~m}$ due to a combination of increasing $\delta^{18} \mathrm{O}_{\mathrm{W}}$ and decreasing $\mathrm{T}$, with

254 most of the change above $2000 \mathrm{~m}$. The Bering Sea $\delta^{13} \mathrm{C}_{\mathrm{DIC}}$ and $\delta^{18} \mathrm{O}_{\mathrm{C}}$ are slightly lower than the 255 values at Emperor Seamounts, consistent with the higher regenerated nutrient and lower oxygen 256 concentrations, as well as the slightly warmer and fresher water observed in the Bering Sea, 257 compared to the open North Pacific (Roden, 1995). The relatively high $\delta^{18} \mathrm{O}_{\mathrm{C}}$ and high $\delta^{13} \mathrm{C}_{\text {DIC }}$

258 values above $1000 \mathrm{~m}$ in the Okhotsk Sea shows the extent of the well-ventilated,

259 chlorofluorocarbon-enriched, cold, nutrient-depleted brine (Wong et al., 1998). Deeper than 260 around 1000 m, the Okhotsk Sea profiles are similar to the Emperor and Bering profiles. 
262 The coretop Uvigerina $\delta^{18} \mathrm{O}$ (Figure 8a) is generally consistent with equilibrium offset corrected

263 Cibicidoides (+0.5\%o; Fontanier et al., 2006) at depths where there are data from both species.

264 Coretop Emperor and Okhotsk $\delta^{18} \mathrm{O}$ and Bering $\delta^{18} \mathrm{O}>2 \mathrm{~km}$ are also broadly consistent with

$265 \delta^{18} \mathrm{O}_{\mathrm{c}}$ in shape of the profile, where there is little vertical structure (Figure 9a) and the values are

266 slightly higher $\left(0.1-0.2 \%\right.$ ) than $\delta^{18} \mathrm{O}_{\mathrm{C}}$ (Figure 9a). For Bering $\delta^{18} \mathrm{O}<2 \mathrm{~km}$, there is a larger

267 offset of $\sim 0.6 \%$ of the coretop data to more positive values from $\delta^{18} \mathrm{O}_{\mathrm{C}}$ (Figure 8a, 9a).

268

269 The coretop $\delta^{13} \mathrm{C}$ (Figure 8b) is more variable than the $\delta^{18} \mathrm{O}$ (compare standard deviations of 270 offsets in Figures 9a and 9b). The offset-corrected (+0.9\%; Mix et al., 1995) coretop Uvigerina

$271 \delta^{13} \mathrm{C}$ is consistent with Cibicidoides. The Emperor and Ohkotsk profiles as well as the Bering

272 profile $>2 \mathrm{~km}$ are consistent with $\delta^{13} \mathrm{C}_{\mathrm{DIC}}$, where average offsets from $\delta^{13} \mathrm{C}_{\mathrm{DIC}}$ overlap with zero

273 (Figure 9b), and where the Bering $\delta^{13} \mathrm{C}$ values are systematically more negative than the

274 Emperor $\delta^{13} \mathrm{C}$, similar to the modern $\delta^{13} \mathrm{C}_{\text {DIC }}$ (Figure 8b). Above $2 \mathrm{~km}$, however, Bering $\delta^{13} \mathrm{C}$ is 275 offset to more positive values than $\delta^{13} \mathrm{C}_{\text {DIC }}$ by $\sim 0.4 \%$.

276

277 One possible contribution to the positive anomalies in both $\delta^{18} \mathrm{O}$ and $\delta^{13} \mathrm{C}$ at $500-2000 \mathrm{~m}$ water 278 depth in the Bering Sea is the carbonate ion effect (Spero et al., 1997). The oxygen minimum 279 zone is more intense in the Bering Sea, and is associated with a higher concentration of respired 280 nutrients and carbon dioxide than in the Okhotsk Sea at these depths (Talley, 2007). This results 281 in a lower carbonate ion concentration, and an expected increase in both $\delta^{18} \mathrm{O}$ and $\delta^{13} \mathrm{C}$ of 282 equilibrium calcite, which is consistent with our observations. Though the carbonate ion effect is 
283 not known for the Bering and Okhotsk OMZs during the LGM, the sense of the bias would be

284 the same for the $\delta^{18} \mathrm{O}$ and $\delta^{13} \mathrm{C}$, either both positive or both negative.

285

286

The LGM depth profiles

287 All of the LGM $\delta^{18} \mathrm{O}$ profiles are offset to more positive values than the modern profile corrected 288 for the whole-ocean change (+1.1\%o; Labeyrie et al., 2002) (Figure 8c, 9c). Keigwin (1998)

289 observed that the Okhotsk $\delta^{18} \mathrm{O}$ in both Uvigerina and Cibicidoides decreases by $0.5-0.6 \%$ from

2902000 to $1000 \mathrm{~m}$ water depth, a steeper gradient than the modern $\delta^{18} \mathrm{O}_{\mathrm{C}}$. This can be seen in the

291 larger average offset of $\delta^{18} \mathrm{O}$ from $\delta^{18} \mathrm{O}_{\mathrm{C}}$ for Okhotsk than Emperor and the decreasing $\left[\delta^{18} \mathrm{O}-\right.$

$\left.292 \delta^{18} \mathrm{O}_{\mathrm{C}}\right]$ with decreasing $\delta^{18} \mathrm{O}_{\mathrm{C}}$ (Figure 9c). In the Bering Sea, the water column is not as well

293 sampled as in the Okhotsk and Emperor study areas, but it appears that the shape of the profile

294 was also different than the modern. The $\delta^{18} \mathrm{O}$ is relatively uniform from $3200 \mathrm{~m}$ water depth to

295 1500-2000 m water depth, and decreases $\sim 0.5 \%$ by 700 m water depth.

296

297 The LGM Bering $\delta^{13} \mathrm{C}$ profile is relatively uniform from 700 to $3200 \mathrm{~m}$ water depth, in contrast 298 to the modern profile, which gradually decreases by $0.5 \%$ from 4000 to $500 \mathrm{~m}$. This is also in 299 contrast to the Okhotsk profile, where both Uvigerina and Cibicidoides decrease by 0.5\%o from 3002000 to $1000 \mathrm{~m}$ water depth. The Emperor $\delta^{13} \mathrm{C}$ is very similar to the modern $\delta^{13} \mathrm{C}_{\text {DIC }}$ corrected 301 for the whole-ocean change (-0.32\%; Duplessey et al., 1988).

302

303 DISCUSSION

304 The Holocene-LGM profiles 
305 Keigwin (1998) interpreted the relatively high LGM Emperor $\delta^{18} \mathrm{O}$ of Cibicidoides as indicating 306 a colder and saltier deep water than today. This is consistent with estimates of the $\theta$ and S based 307 on porewater profiles of chlorinity and $\delta^{18} \mathrm{O}_{\mathrm{W}}$ that show that density differences in the LGM 308 ocean were dominated by salinity, and that the deep ocean was near its freezing point (Adkins et 309 al., 2002). The $\delta^{18} \mathrm{O}$ in the deep LGM Bering Sea is similar but slightly higher than Emperor 310 values and uniform, showing that this cold and salty deep water may also have filled the deep

311 Bering Sea. This deep water appeared poorly ventilated, based on benthic-planktonic

312 radiocarbon age differences from the eastern equatorial Pacific (Shackleton et al., 1988) and Gulf 313 of Alaska (Galbraith et al., 2007; Davies-Walczak et al., 2014).

315 The LGM divide between the poorly-ventilated deep water below and the well-ventilated 316 intermediate water above is at $\sim 2000 \mathrm{~m}$ in the Okhotsk Sea, similar to $\delta^{13} \mathrm{C}$ profiles from sites 317 further south at the Japan Margin (Matsumoto et al., 2002), Ontong Java Plateau (Herguera et al., 318 1992), and Gulf of California (Keigwin, 2002). If we take the Bering stable isotope data from $319<2000 \mathrm{~m}$ at face value, the $\delta^{18} \mathrm{O}$ is $\sim 0.3 \%$ higher and the Uvigerina $\delta^{13} \mathrm{C}$ is up to $\sim 0.5 \%$ lower 320 than in the Okhotsk above the divide. Even though the potential bias in these OMZ-depth data 321 due to the carbonate ion effect is unknown, since the Bering-Okhotsk isotopic difference has a 322 different sign for $\delta^{18} \mathrm{O}$ as $\delta^{13} \mathrm{C}$, it's clear that the water masses $<2000 \mathrm{~m}$ had distinct compositions 323 in the two basins. 
326 Though we don't fully understand the difference between the Holocene Bering foraminiferal

327 stable isotopes and hydrography, or whether this difference varied through time, it is instructive

328 to examine possible implications of the LGM profiles.

330 If we consider the scenario where intermediate water was produced only in the Okhotsk Sea then

331 flowed into the Bering Sea, then it would require that Okhotsk water $\delta^{18} \mathrm{O}$ be modified in transit

332 through mixing with cooler and/or saltier water, since the Bering $\delta^{18} \mathrm{O}<2 \mathrm{~km}$ is $0.3 \%$ more

333 positive than the Okhotsk. This could happen if the newly ventilated Okhotsk water entrained

334 some of the deep, high- $\delta^{18} \mathrm{O}$ water mass as it passed through the straits in the Kuril and Aleutian

335 Islands, where WOCE transects show intense tidal mixing (Freeland et al., 1998; Roden, 1995),

336 and transport of water properties in mesoscale eddies (Maslowski et al., 2008). We can predict

337 this modification would result in the low- $\delta^{18} \mathrm{O}$ water in the Bering Sea to have $\delta^{13} \mathrm{C}$ intermediate

338 in value between the Okhotsk and Emperor values. The Bering $\delta^{13} \mathrm{C}$ does not appear to show this

339 enrichment in $\delta^{13} \mathrm{C}$ (Figure 8d, Figure 9), but rather, maintains low values similar to that of the

340 glacial deep water. This water mass mixing argument would hold even if the Bering stable

341 isotope data $<2 \mathrm{~km}$ water depth were translated to more positive or more negative values due to

342 the carbonate ion effect.

344 Alternatively, if we consider the scenario where the Okhotsk did not produce intermediate water,

345 but was downstream of a Bering Sea source, then it would require that the low- $\delta^{18} \mathrm{O}$ water be

346 modified by $-0.3 \%$ by mixing with warmer and/or fresher water by the time it reaches the

347 Okhotsk Sea. This modification would also need to be accompanied by an increase in $\delta^{13} \mathrm{C}$ of up

348 to $0.5 \%$. This $\delta^{13} \mathrm{C}$ increase is in the opposite direction than would be expected from water mass 
349 aging and input of low- $\delta{ }^{13} \mathrm{C}$ respired organic matter, and seems unlikely, even if the Bering

350 stable isotope data were translated to more positive or more negative values due to the carbonate

351 ion effect.

352

353 A third alternative is that the Bering Sea and Okhotsk Sea both produced relatively well-

354 ventilated intermediate water during the LGM. There is evidence of expanded LGM sea ice

355 compared to today in both the Bering (Sancetta and Robinson, 1983; Katsuki and Takahashi,

356 2005) and Okhotsk (Okazaki et al., 2005) Seas. The surface waters in the two basins may have

357 different isotopic composition because of differences in the hydrological cycle, local productivity

358 and air-sea gas exchange resulting in distinct preformed $\delta^{18} \mathrm{O}$ and $\delta^{13} \mathrm{C}$.

360 Based on the distribution of C. davisiana, Tanaka and Takahashi (2005) argued that the solely

361 the Bering Sea was a source of intermediate water during MIS2. However, if dense water formed

362 in both marginal seas, one possibility is that the Bering Sea source water was formed during sea

363 ice formation, and was therefore associated with the hydrography favorable for high abundance

364 of C. davisiana, while Okhotsk source water was associated with a different process. It is also

365 possible that the distinct water mass in the Okhotsk originated elsewhere.

367 The $\delta^{13} \mathrm{C}_{\text {DIC }}$ of surface ocean water varies spatially, depending on biological uptake and air-sea

368 carbon dioxide exchange (Lynch-Stieglitz et al., 1995), where $\delta^{13} C_{\text {DIC }}$ is enriched with biological

369 productivity, but also enriched with lower sea surface temperatures and depleted with carbon

370 dioxide invasion into the surface ocean. During the LGM, productivity was low in both the

371 Okhotsk and Bering Seas (Kohfeld and Chase, 2011), possibly due to expanded sea ice, which 
372 also would limit air-sea gas exchange, though in the Bering Sea, seasonal ice did not appear to

373 reach as far into the center of the basin as the Bowers Ridge (Katsuki and Takahashi, 2005).

374 Differences in LGM ice extent, productivity and air-sea exchange between the Okhotsk and

375 Bering Seas could result in different surface water $\delta^{13} \mathrm{C}$, and therefore different pre-formed

$376 \quad \delta^{13} \mathrm{C}_{\mathrm{DIC}}$ of newly-ventilated intermediate water.

378 The $\delta^{18} \mathrm{O}_{\mathrm{W}}$ of modern precipitation in the Okhotsk Sea is a few permil lower than in the Bering

379 Sea, because of the slightly cooler temperatures in the Okhotsk, and the influence of the land

380 masses that surround this marginal sea on three sides (Bowen et al., 2003). The modern $\delta^{18} \mathrm{O}_{\mathrm{w}}$ of

381 surface water is slightly lower in the Okhotsk Sea, but similar in the two basins, both showing

382 the strong influence of seasonal sea ice, and a shallow slope to the $\delta^{18} \mathrm{O}_{\mathrm{w}}$-salinity relationship

383 (LeGrande and Schmidt, 2006). This difference between the precipitation and surface water

$384 \delta^{18} \mathrm{O}_{\mathrm{W}}$ of these two basins is the same sense as the difference between the $\delta^{18} \mathrm{O}_{\mathrm{W}}$ profiles above

$3852000 \mathrm{~m}$ water depth, where the Bering is higher than the Okhotsk.

387 Glacial-interglacial patterns

388 The benthic $\delta^{18} \mathrm{O}$ data show that the structure of the water column differs between glacials and

389 today (Figure 7). The glacial-interglacial amplitude of the U1339 record (1870 m) is similar to

390 the global benthic stack, while the amplitude of U1342 (820 m) is smaller, resulting in more

391 negative glacial maxima in $\delta^{18} \mathrm{O}$ (Figure 6, 7). Knudson and Ravelo (2015) interpret this lower

392 glacial $\delta^{18} \mathrm{O}$ as a well-ventilated glacial intermediate water mass that formed locally during brine

393 rejection. They argue that the $\delta^{18} \mathrm{O}_{\mathrm{W}}$ at this site was higher during interglacials when, like today,

394 the water at this site was strongly influenced by high- $\delta{ }^{18} \mathrm{O}$ deep water that originated in the 
395 Southern Hemisphere. During glacials, enhanced sea-ice formation would have produced dense 396 water with little oxygen isotope fractionation (Tan and Strain, 1996). The newly-produced water 397 would therefore carry the relatively low $\delta^{18} \mathrm{O}$ signature of high-latitude surface water.

399 The benthic $\delta^{18} \mathrm{O}$ gradient between U1342 and U1339 ranges from 0.4\%o to 0.8\%o (Figure 7, 400 Table 4), larger than the difference in calculated equilibrium calcite of $0.3 \%$ between 820 and $4011870 \mathrm{~m}$ in the modern Bering Sea (Figure 7). Today water at $1870 \mathrm{~m}$, the depth of U1339, is in 402 the core of PDW, and water at $820 \mathrm{~m}$, the depth of U1342, is a mixture of PDW and NPIW. The $40326.8 \sigma_{\theta}$ isopycnal at the core of NPIW in the Bering Sea is quite shallow, at 250-300 m

404 (MacDonald et al., 2001). The larger gradient between these two coring depths during glaciations 405 is consistent with an expanded, well-ventilated intermediate water mass that reached the U1342 406 coring site.

408 Site U1345 (1008 m) can constrain the depth of the hydrographic boundary between the 409 apparently well-ventilated water above recorded by U1342 and the more poorly-ventilated water 410 below recorded by U1339. During glacials MIS 8, 10 and 12 the $\delta^{18} \mathrm{O}$ in U1345 is similar to 411 U1339 (Figure 6), suggesting that the hydrographic boundary was above $1008 \mathrm{~m}$, and the water 412 column from 1008 to $1870 \mathrm{~m}$ was homogeneous. During MIS 2, the $\delta^{18} \mathrm{O}$ in U1345 was $0.2 \%$ 413 lower than at U1339, suggesting that the well-ventilated water penetrated more deeply during 414 this glaciation.

415

416 CONCLUSIONS 
417 We use multi-species benthic stable isotope measurements in two sites from the IODP

418 Expedition to the Bering Sea to assess the structure of the water column during the late

419 Pleistocene. There is a hydrographic divide between relatively high $\delta^{18} \mathrm{O}$ water below and low $420 \quad \delta^{18} \mathrm{O}$ water above during glaciations, which was near or above $\sim 1000 \mathrm{~m}$ water depth. The upper

421 water mass may be relatively well-ventilated, with a low $\delta^{18} \mathrm{O}$ signature that could be the result

422 of formation through brine rejection. In a closer look at the LGM, we find that the upper Bering

423 Sea water column is relatively enriched in ${ }^{18} \mathrm{O}$ and depleted in ${ }^{13} \mathrm{C}$ compared to the Okhotsk Sea.

424 The distinct isotopic signatures in the two marginal seas may indicate that well-ventilated water

425 formed in both basins. These observations suggest that in the late Pleistocene, the glacial

426 circulation of the subarctic Pacific was systematically different than today, with implications for

427 the global heat budget.

428

429 ACKNOWLEDGEMENTS

430 We are grateful to Meredith Annex, Claire Baecher, Miranda Bona, Kalila Booker-Cassano, 431 Galen Corey, Zara Currimjee, Paul Deaderick, Thomas Gaidus, Kathryn Kumamoto, Julia 432 Matejcek, Molly McEntee, Harper Robertson and Susan Trimarchi at Williams College for their 433 help in sample preparation, and Andy Ross, June Padman and Nancy Kyle at OSU, and Dyke 434 Andreassen and Ting Hsieh at UCSC for assistance in sample analysis. Dan McCorkle 435 generously provided the HLY02-02 multicore and hydrocast data and valuable discussions. We 436 thank Hirofumi Asahi, Yusuke Okazaki and Tatsuhiko Sakamoto for providing unpublished data 437 for the LGM time slice. We also thank two anonymous reviewers whose comments helped to 438 improve this manuscript. Support for this project was from the Consortium for Ocean Leadership, 
the National Science Foundation Grant \#0963114 and the Williams College Divisional Research

Funding committee.

441

442

443

444

445

446

447

448

449

450

451

452

453

454

455

456

457

458

459

460

461

462

463

464

465

466

467

468

469

470

\section{REFERENCES}

Adkins, J.F., McIntyre, K., Schrag, D.P., 2002. The salinity, temperature, and $\delta^{18} \mathrm{O}$ of the glacial deep ocean. Science. 298, 1769-1773.

Asahi, H., S. Kender, M. Ikehara, T. Sakamoto, K. Takahashi, A. C. Ravelo, C. A. AlvarezZarikian, B. K. Khim, M. J. Leng. Orbital-scale benthic foraminiferal oxygen isotope stratigraphy at the northern Bering Sea slope site U1343 (IODP Expedition 323) and its Paleistocene paleoceanographic significance. Deep-Sea Research Part II, in press, this volume.

Bernhard, J.M., 1988. Postmortem vital staining in benthic foraminifera: duration and importance in population and distributional studies. J. Foraminifer. Res. 18, 143-146.

Bowen, Gabriel, J., Revenaugh, J., 2003. Interpolating the isotopic composition of modern meteoric precipitation. Water Resour. Res. 39, 1299.

Brunelle, B.G., Sigman, D.M., Cook, M.S., Keigwin, L.D., Haug, G.H., Plessen, B., Schettler, G., Jaccard, S.L., 2007. Evidence from diatom-bound nitrogen isotopes for subarctic Pacific stratification during the last ice age and a link to North Pacific denitrification changes. Paleoceanography 22, PA1215.

Cook, M.S., Keigwin, L.D., Birgel, D., Hinrichs, K.-U., 2011. Repeated pulses of vertical methane flux recorded in glacial sediments from the southeast Bering Sea.

Paleoceanography 26, PA2210.

Corliss, B.H., Emerson, S.R., 1990. Distribution of Rose Bengal stained deep-sea benthic foraminifera from the Nova Scotian continental margin and Gulf of Maine. Deep. Res. 37, 381-400.

Davies-Walczak, M., Mix, A. C., Stoner, J. S., Southon, J. R., Cheseby, M., \& Xuan, C., 2014. Late Glacial to Holocene radiocarbon constraints on North Pacific Intermediate Water ventilation and deglacial atmospheric $\mathrm{CO}_{2}$ sources. Earth and Planetary Science Letters, 397, 57-66.

Duplessy, J.-C., Shackleton, N.J., Fairbanks, R.G., Labeyrie, L., Oppo, D., Kallel, N., 1988. Deepwater source variations during the last climatic cycle and their impact on the global deepwater circulation. Paleoceanography 3, 343-360. 
Eakins, B.W., Sharman, G.F., 2010. Volumes of the World's Oceans from ETOPO1. NOAA National Geophysical Data Center, Boulder, CO.

Emile-Geay, J., Cane, M.A., Naik, N., Seager, R., Clement, A.C., van Geen, A., 2003. Warren revisited: atmospheric freshwater fluxes and "Why is no deep water formed in the North Pacific”. J. Geophys. Res. 108, 3178.

Fontanier, C., Mackensen, A., Jorissen, F. J., Anschutz, P., Licari, L., \& Griveaud, C., 2006. Stable oxygen and carbon isotopes of live benthic foraminifera from the Bay of Biscay: Microhabitat impact and seasonal variability. Marine Micropaleontology, 58(3), 159-183.

Freeland, H.J., Bychkov, A.S., Whitney, F., Taylor, C., Wong, C.S., Yurasov, G.I., 1998. WOCE section P1W in the Sea of Okhotsk 1. Oceanographic data description. J. Geophys. Res. 103, 15613-15623.

Galbraith, E.D., Jaccard, S.L., Pedersen, T.F., Sigman, D.M., Haug, G.H., Cook, M., Southon, J.R., Francois, R., 2007. Carbon dioxide release from the North Pacific abyss during the last deglaciation. Nature 449, 890-893.

Herguera, J.C., Berger, W.H., Jansen, E., 1992. Evidence for a bathyal front at $2000 \mathrm{~m}$ depth in the glacial Pacific, based on a depth transect on Ontong Java Plateau. Paleoceanography 7, 273-288.

Herguera, J. C., Paull, C. K., Perez, E., Ussler, W., \& Peltzer, E., 2014. Limits to the sensitivity of living benthic foraminifera to pore water carbon isotope anomalies in methane vent environments. Paleoceanography, 29(3), 273-289.

Horikawa, K., Asahara, Y., Yamamoto, K., Okazaki, Y., 2010. Intermediate water formation in the Bering Sea during glacial periods: Evidence from neodymium isotope ratios. Geology 38, 435-438.

Katsuki, K., Takahashi, K., 2005. Diatoms as paleoenvironmental proxies for seasonal productivity, sea-ice and surface circulation in the Bering Sea during the late Quaternary. Deep Sea Res. Part II 52, 2110-2130.

Keigwin, L.D., 1998. Glacial-age hydrography of the far Northwest Pacific Ocean. Paleoceanography 13, 323-339.

Keigwin, L.D., 2002. Late Pleistocene-Holocene paleoceangraphy and ventilation of the Gulf of California. J. Oceanogr. 58, 421-432.

Key, R.M., Quay, P.D., Schlosser, P., McNichol, A.P., von Reden, K.F., Schneider, R.J., Elder, K.L., Stuiver, M., Östlund, H.G., 2002. WOCE radiocarbon IV: Pacific Ocean results; P10, P13N, P14C, P18, P19, S4P. Radiocarbon 44, 239-392. 
Kim, S.-T., O'Neil, J.R., 1997. Equilibrium and nonequilibrium oxygen isotope effects in synthetic carbonates. Geochim. Cosmochim. Acta 61, 3461-3475.

Knudson, K., Ravelo, A.C., 2015. North Pacific Intermediate Water circulation enhanced by the closure of the Bering Strait. Paleoceanography, 30(10), 1287-1304.

Kohfeld, K.E., Chase, Z., 2011. Controls on deglacial changes in biogenic fluxes in the North Pacific Ocean. Quat. Sci. Rev. 30, 3350-3363.

Labeyrie, L., Waelbroeck, C., Duplessy, J.-C., 2002. Constraints on the ocean oxygen isotopic enrichment between the Last Glacial Maximum and the Holocene: Paleoceanographic implications. Quat. Sci. Rev. 21, 315-330.

Leduc, G., Vidal, L., Tachikawa, K., Rostek, F., Sonzogni, C., Beaufort, L., Bard, E., 2007. Moisture transport across Central America as a positive feedback on abrupt climatic changes. Nature 445, 908-911.

LeGrande, A.N., Schmidt, G.A., 2006. Global gridded data set of the oxygen isotopic composition in seawater. Geophys. Res. Lett. 33, L12604.

Lehmann, M.F., Sigman, D.M., McCorkle, D.C., Brunelle, B.G., Hoffmann, S., Kienast, M., Cane, G., Clement, J., 2005. Origin of the deep Bering Sea nitrate deficit: Constraints from the nitrogen and oxygen isotopic composition of water column nitrate and benthic nitrate fluxes 19, GB4005.

Lisiecki, L.E., Raymo, M.E., 2005. A Pliocene-Pleistocene stack of 57 globally distributed benthic $\delta^{18} \mathrm{O}$ records. Paleoceanography 20, PA1003.

Lynch-Stieglitz, J., Stocker, T.F., Broecker, W.S., Fairbanks, R.G., 1995. The influence of airsea exchange on the isotopic composition of oceanic carbon: Observations and modeling. Global Biogeochem. Cycles 9, 653-665.

MacDonald, A.M., Suga, T., Curry, R.G., 2001. An isopycnally averaged North Pacific climatology. J. Atmos. Ocean. Technol. 18, 394-420.

Maslowski, W., Roman, R., \& Kinney, J. C., 2008. Effects of mesoscale eddies on the flow of the Alaskan Stream. Journal of Geophysical Research: Oceans (1978-2012), 113(C7).

Matsumoto, K., Oba, T., Lynch-Stieglitz, J., Yamamoto, H., 2002. Interior hydrography and circulation of the glacial Pacific Ocean. Quat. Sci. Rev. 21, 1693-1704.

McCorkle, D.C., Corliss, B.H., Farnham, C.A., 1997. Vertical distributions and stable isotopic compositions of live (stained) benthic foraminifera from the North Carolina and California continental margins. Deep. Res. 44, 983-1024. 
McCorkle, D.C., Keigwin, L.D., Corliss, B.H., Emerson, S.R., 1990. The influence of microhabitats on the carbon isotopic composition of deep-sea benthic foraminifera. Paleoceanography 5, 161-185.

McNichol, A.P., Jones, G.A., Hutton, D.L., Gagnon, A.R., 1994. The rapid preparation of seawater $\mathrm{TCO}_{2}$ for radiocarbon analysis at the National Oceanic and Atmsopheric Sciences AMS Facility. Radiocarbon 36, 237-246.

Mix, A.C., Pisias, N.G., Rugh, W., Wilson, J., Morey, A., Hagelberg, T.K., 1995. Benthic foraminifer stable isotope record from Site 849 (0-5 Ma): local and global climate changes. Proc. Ocean Drill. Program, Sci. Results 138, 371-412.

Ohkushi, K., Itaki, T., Nemoto, N., 2003. Last glacial-Holocene change in intermediate-water ventilation in the Northwestern Pacific. Quat. Sci. Rev. 22, 1477-1484.

Okazaki, Y., Takahashi, K., Katsuki, K., Ono, A., Hori, J., Sakamoto, T., Uchida, M., Shibata, Y., Ikehara, M., Aoki, K., 2005. Late Quaternary paleoceanographic changes in the southwestern Okhotsk Sea: Evidence from geochemical, radiolarian, and diatom records. Deep Sea Res. Part II 52, 2332-2350.

Ostermann, D. R., and W. B. Curry, 2000. Calibration of stable isotopic data: an enriched $\delta^{18} \mathrm{O}$ standard used for source gas mixing detection and correction. Paleoceanography, 15(3), 353-360.

Pierre, C., Blanc-Valleron, M. M., Caquineau, S., März, C., Ravelo, A.C., Takahashi, K., and Zarikian, C.A. Mineralogical, geochemical and isotopic characterization of authigenic carbonates from the methane-bearing sediments of the Bering Sea continental margin (IODP Expedition 323, Sites U1343-U1345). Deep Sea Research Part II: Topical Studies in Oceanography, in press, this volume. doi:10.1016/j.dsr2.2014.03.011

Rella, S. F., Tada, R., Nagashima, K., Ikehara, M., Itaki, T., Ohkushi, K. I., Sakamoto, T., Harada, N., Uchida, M., 2012. Abrupt changes of intermediate water properties on the northeastern slope of the Bering Sea during the last glacial and deglacial period. Paleoceanography, 27(3).

Roden, G.I., 1995. Aleutian Basin of the Bering Sea: thermohaline, oxygen, nutrient, and current structure in July 1993. J. Geophys. Res. 100, 13,539-13,554.

Sancetta, C., Robinson, S.W., 1983. Diatom evidence on Wisconsin and Holocene events in the Bering Sea. Quat. Res. 20, 232-245.

Schlung, S.A., Ravelo, A.C., Aiello, I.W., Andreasen, D.H., Cook, M.S., Drake, M., Dyez, K.A., Guilderson, T.P., LaRiviere, J.P., Stroynowski, Z., Takahashi, K., 2013. Millennial-scale climate change and intermediate water circulation in the Bering Sea from 90 ka: A highresolution record from IODP Site U1340. Paleoceanography 28, 54-67. 
Schrag, D.P., Adkins, J.F., McIntyre, K., Alexander, J., Hodell, D.A., Charles, C.D., McManus, J.F., 2002. The oxygen isotopic composition of seawater during the Last Glacial Maximum. Quat. Sci. Rev. 21, 331-342.

Shackleton, N. J., 1974. Attainment of isotopic equilibrium between ocean water and the benthonic foraminifera genus Uvigerina: isotopic changes in the ocean during the last glacial. In: Les méthodes quantitatives d'étude des variations du climat au cors du Pléistocène. Colloques Internationaux du C. N. R. S., \#219.

Shackleton, N.J., Duplessy, J.-C., Arnold, M., Maurice, P., Hall, M.A., Cartlidge, J., 1988. Radiocarbon age of last glacial Pacific deep water. Nature 335, 708-711.

Shcherbina, A.Y., Talley, L.D., Rudnick, D.L., 2003. Direct observations of North Pacific ventilation: brine rejection in the Okhotsk Sea. Science 302, 1952-1955.

Spero, H. J., Bijma, J., Lea, D. W., \& Bemis, B. E., 1997. Effect of seawater carbonate concentration on foraminiferal carbon and oxygen isotopes. Nature, 390(6659), 497-500.

Takahashi, K., Ravelo, A.C., Alvarez Zarikian, C., Scientists, E. 323, 2011. Proceedings of the Integrated Ocean Drilling Program, Expedition 323. Tokyo.

Tanaka, S., and Takahashi, K., 2005. Late Quaternary paleoceanographic changes in the Bering Sea and the western subarctic Pacific based on radiolarian assemblages. Deep Sea Research Part II: Topical Studies in Oceanography, 52(16), 2131-2149.

Talley, L.D., 2003. Shallow, intermediate, and deep overturning components of the global heat budget. J. Phys. Oceanogr. 33, 530-560.

Talley, L. D., 2007. Hydrographic atlas of the World Ocean Circulation Experiment (WOCE): Volume 2: Pacific Ocean. M. D. Sparrow, P. Chapman, \& J. Gould (Eds.). WOCE International Project Office.

Tan, F.C., Strain, P.M., 1996. Sea ice and oxygen isotopes in Foxe Basin, Hudson Bay, and Hudson Strait, Canada. J. Geophys. Res. 101, 20,869-20,876.

Van Scoy, K.A., Olson, D.B., Fine, R.A., 1991. Ventilation of North Pacific Intermediate Waters: the role of the Alaskan Gyre. J. Geophys. Res. 96, 16,801-816,810.

Warren, B.A., 1983. Why is no deep water formed in the North Pacific? J. Mar. Res. 41, 327347.

Wehrmann, L. M., Risgaard-Petersen, N., Schrum, H. N., Walsh, E. A., Huh, Y., Ikehara, M., Pierre, C., D'Hondt, S., Ferdelman, T. G., Ravelo, A. C., Takahashi, K., Alvarez-Zarikian, C., The Integrated Ocean Drilling Program Expedition 323 Scientific Party. Coupled organic and inorganic carbon cycling in the deep subseafloor sediment of the northeastern Bering Sea Slope (IODP Exp. 323). Chemical Geology, 284(3), 251-261. 
605 Wessel, P., Smith, W.H.F., 1998. New, improved version of Generic Mapping Tools released. $606 \quad$ EOS Trans. Am. Geophys. Union 79, 579.

607 Wong, C.S., Matear, R.J., Freeland, H.J., Whitney, F.A., Bychkov, A.S., 1998. WOCE line P1W 608 in the Sea of Okhotsk: 2. CFCs and the formation rate of intermediate water. J. Geophys. 609 Res. 103, 15,625-15,642.

610 
611 Table 1: The mean offset of the $\delta^{18} \mathrm{O}$ of four benthic species from the $\delta^{18} \mathrm{O}$ of $U$. peregrina in 612 samples where both were measured (Figure 5). This correction is applied to the $\delta^{18} \mathrm{O}$ data in

613 Figure 3.

\begin{tabular}{c|c|c|c}
\hline & $\mathrm{U} 1345 \delta^{18} \mathrm{O}$ & $\mathrm{U} 1339 \delta^{18} \mathrm{O}$ & $\mathrm{U} 1339 \delta^{13} \mathrm{C}$ \\
\hline U. senticosa & & $-0.02 \pm 0.19(\mathrm{n}=45)$ & $0.29 \pm 0.32(\mathrm{n}=45)$ \\
N. labradorica & $-0.11 \pm 0.13(\mathrm{n}=82)$ & $-0.14 \pm 0.09(\mathrm{n}=6)$ & \\
G. affinis & $0.13 \pm 0.13(\mathrm{n}=109)$ & & \\
E. batialis & & $-0.79 \pm 0.24(\mathrm{n}=41)$ & \\
\hline
\end{tabular}

614

615

616

Table 2: Age model for U1339 and U1345, based on wiggle-matching the benthic $\delta^{18} \mathrm{O}$

617 stratigraphy to the Lisiecki and Raymo (2005) stack.

\begin{tabular}{c|cc|cc|cc} 
& \multicolumn{3}{|c|}{ Stack } & \multicolumn{2}{c}{ U1345 } & \multicolumn{2}{c}{ U1339 } \\
& End (ka) & Start (ka) & Top (mbsf) & $\begin{array}{c}\text { Bottom } \\
\text { (mbsf) }\end{array}$ & Top (mbsf) & $\begin{array}{c}\text { Bottom } \\
\text { (mbsf) }\end{array}$ \\
\hline MIS 1 & 0 & 14 & $-0.5 \pm 1$ & $6.0 \pm 0.5$ & $-0.5 \pm 1$ & $3.5 \pm 0.5$ \\
MIS 5 & 71 & 130 & $23.6 \pm 1$ & $35.2 \pm 1.5$ & $20.5 \pm 1$ & $34.6 \pm 1$ \\
MIS 7 & 191 & 243 & $47.8 \pm 1$ & $68.7 \pm 1$ & $54.2 \pm 1$ & $70.5 \pm 1.5$ \\
MIS 9 & 300 & 337 & $87.0 \pm 2$ & $98.6 \pm 3$ & $83.2 \pm 2$ & $91.8 \pm 1$ \\
MIS 11 & 374 & 424 & $115.3 \pm 2$ & $130.6 \pm 2$ & $98.5 \pm 1$ & $112.0 \pm 1.5$ \\
MIS 13 & 478 & 533 & $148.7 \pm 2$ & & $123.7 \pm 2$ & $135.9 \pm 1.5$ \\
MIS 15 & 565 & 621 & & & $141.5 \pm 1.5$ & $154.7 \pm 1$ \\
MIS 17 & 676 & 712 & & & $164.5 \pm 1.5$ & $171.2 \pm 1$ \\
MIS 19 & 761 & 790 & & & $196.8 \pm 2$ & $185.0 \pm 1$ \\
MIS 21 & 814 & 866 & & & & \\
\hline
\end{tabular}

618

619 
620 Table 3: Uvigerina Holocene and LGM time slice data from this study, 17JPC (Brunelle et al., 621 2007), 51JPC and 57JPC (Cook et al., 2011), U1340 (Schlung et al., 2013), U1341 (Sakamoto, 622 personal communication), U1342 (Knudson and Ravelo, in review), U1343 (Asahi, personal 623 communication), and U1344 (Okazaki, personal communication), HLY02-02 multicore data are 624 of Rose-Bengal stained foraminifera. These are the original data, without species-species offset 625 corrections.

\begin{tabular}{|c|c|c|c|c|c|c|c|c|}
\hline \multirow[t]{2}{*}{ Core name } & \multirow{2}{*}{$\begin{array}{l}\text { Water } \\
\text { depth } \\
(\mathrm{m})\end{array}$} & \multirow[t]{2}{*}{ Species } & \multicolumn{3}{|c|}{ Holocene } & \multicolumn{3}{|c|}{ LGM } \\
\hline & & & $\begin{array}{l}\text { Core } \\
\text { Depth } \\
(\mathrm{m})\end{array}$ & $\begin{array}{c}\delta^{13} \mathrm{C} \\
\text { (\%о VPDB) }\end{array}$ & $\begin{array}{c}\delta^{18} \mathrm{O} \\
\text { (\% VPDB) }\end{array}$ & $\begin{array}{l}\text { Core } \\
\text { Depth } \\
(\mathrm{m})\end{array}$ & $\begin{array}{c}\delta^{13} \mathrm{C} \\
\text { (\% VPDB) }\end{array}$ & $\begin{array}{c}\delta^{18} \mathrm{O} \\
\text { (\%о VPDB) }\end{array}$ \\
\hline HLY02-02-57JPC & 700 & U. peregrina & 0.05 & -0.80 & 3.25 & 0.88 & -1.10 & 4.70 \\
\hline HLY02-02-24MC & 714 & U. peregrina & 0.01 & -1.13 & 3.43 & - & - & - \\
\hline $\mathrm{U} 1342$ & 819 & U. peregrina & - & - & - & 0.55 & -1.08 & 4.57 \\
\hline U1345 & 1008 & U. peregrina & 0.01 & -1.02 & 3.38 & 7.36 & -1.20 & 4.92 \\
\hline HLY02-02-56MC & 1015 & U. peregrina & 0.01 & -1.05 & 3.21 & - & - & - \\
\hline HLY02-02-2MC & 1105 & U. peregrina & 0.01 & -0.90 & 3.42 & - & - & - \\
\hline HLY02-02-3JPC & 1132 & U. peregrina & 0.08 & -0.59 & 3.28 & - & - & - \\
\hline HLY02-02-50MC & 1456 & U. peregrina & 0.01 & -1.15 & 3.50 & - & - & - \\
\hline $\mathrm{U} 1340$ & 1295 & U. peregrina & -0.04 & -0.95 & 3.75 & 2.10 & -1.12 & 5.03 \\
\hline HLY02-02-51JPC & 1467 & U. peregrina & 0.12 & -0.68 & 3.34 & 3.76 & -1.25 & 5.29 \\
\hline U1339 & 1868 & U. peregrina & 0.01 & -1.28 & 3.74 & 5.34 & -1.55 & 5.24 \\
\hline HLY02-02-43MC & 1889 & U. peregrina & 0.01 & -1.29 & 3.66 & - & - & - \\
\hline $\mathrm{U} 1343$ & 1953 & $\begin{array}{l}\text { U. peregrina } \\
U . \text { senticosa }\end{array}$ & 0.01 & -1.07 & 3.67 & 4.23 & -0.68 & 5.05 \\
\hline U1341 & 2140 & U. senticosa & 0.65 & -1.10 & 3.35 & 2.15 & -0.87 & 5.20 \\
\hline HLY02-02-17JPC & 2209 & U. senticosa & 0.20 & -0.73 & 3.39 & 2.82 & -0.73 & 5.35 \\
\hline HLY02-02-16MC & 2216 & $\begin{array}{l}\text { C. mundulus } \\
\text { C. mundulus }\end{array}$ & 0.01 & $\begin{array}{l}-0.39 \\
-0.41 \\
\end{array}$ & $\begin{array}{l}2.99 \\
2.96 \\
\end{array}$ & - & - & - \\
\hline HLY02-02-31MC & 2910 & C. kullenbergi & 0.01 & -0.05 & -2.87 & - & - & - \\
\hline U1344 & 3173 & U. senticosa & 0.01 & -0.58 & 3.38 & 8.71 & -1.01 & 5.27 \\
\hline HLY02-02-5MC & 3449 & $\begin{array}{c}\text { U. peregrina } \\
\text { U. senticosa } \\
\text { Cibicidoides sp. } \\
\text { Cibicidoides sp. }\end{array}$ & 0.01 & $\begin{array}{l}-0.77 \\
-0.76 \\
-0.39 \\
-0.39\end{array}$ & $\begin{array}{l}3.38 \\
3.54 \\
2.80 \\
2.71\end{array}$ & - & - & - \\
\hline
\end{tabular}

626

627

628

Table 4: Uvigerina time slice data.

\begin{tabular}{|c|c|c|c|c|c|c|c|c|c|}
\hline & \multicolumn{3}{|c|}{$\begin{array}{c}\text { U1342 } \\
\text { (819 m) }\end{array}$} & \multicolumn{3}{|c|}{$\begin{array}{c}\mathrm{U} 1345 \\
\text { (1008 m) }\end{array}$} & \multicolumn{3}{|c|}{$\begin{array}{c}\text { U1339 } \\
\text { (1868 m) }\end{array}$} \\
\hline & $\begin{array}{l}\text { Core } \\
\text { Depth } \\
\text { (m) }\end{array}$ & Species & $\begin{array}{l}\delta^{18} \mathrm{O} \\
\text { (\%o } \\
\text { VPDB) }\end{array}$ & $\begin{array}{l}\text { Core } \\
\text { Depth } \\
\text { (m) }\end{array}$ & Species & $\begin{array}{l}\delta^{18} \mathrm{O} \\
(\% \text { o } \\
\text { VPDB) }\end{array}$ & $\begin{array}{l}\text { Core } \\
\text { Depth } \\
\text { (m) }\end{array}$ & Species & $\begin{array}{l}\delta^{18} \mathrm{O} \\
(\% \\
\text { VPDB) }\end{array}$ \\
\hline MIS 2 & 0.55 & & 4.57 & 7.36 & & 4.92 & 5.34 & & 5.24 \\
\hline MIS 6 & 139.92 & & 4.27 & & & & 35.85 & & 5.12 \\
\hline MIS 8 & 247.03 & & 4.12 & 71.24 & & 4.74 & 71.39 & & 4.71 \\
\hline MIS 10 & 339.56 & & 4.27 & 101.66 & & 4.73 & 93.25 & & 4.71 \\
\hline MIS 12 & 432.20 & & 4.66 & 134.23 & & 4.99 & 112.53 & & 5.07 \\
\hline MIS 14 & 532.09 & & 4.01 & & & & 137.83 & & 4.72 \\
\hline MIS 16 & 629.86 & & 4.33 & & & & 156.71 & & 5.13 \\
\hline MIS 18 & 715.44 & & 4.21 & & & & 172.30 & & 4.77 \\
\hline MIS 20 & 798.25 & & 4.30 & & & & 187.97 & & 4.90 \\
\hline MIS 22 & 877.46 & & 4.57 & & & & 207.18 & & 4.85 \\
\hline
\end{tabular}




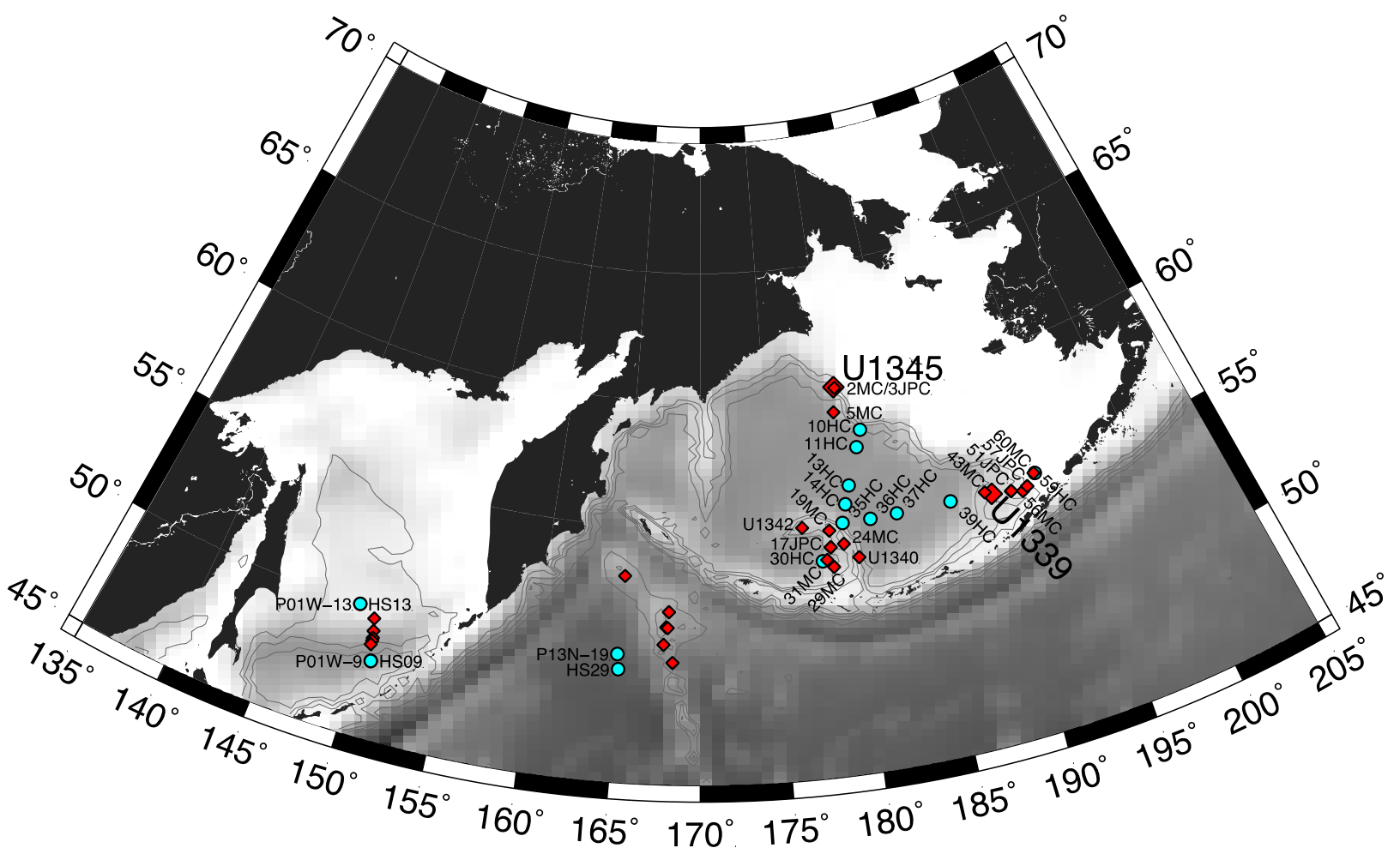

Figure 1: Map of study area with coring and hydrocast station locations referred to in the text. Large red diamonds show the U1345 and U1339 coring locations, and small diamonds show coring locations for other data from the Bering Sea (see Table 3), and the Okhotsk Sea and

634 Emperor Seamounts (see Keigwin, 1998). The Okhotsk and Emperor hydrostation data are from 635 Keigwin (1998) and WOCE. The bathymetry is from Smith and Sandwell (1997), contour 636 interval is 1000 m. Map made with Generic Mapping Tools (Wessel and Smith, 1998). 

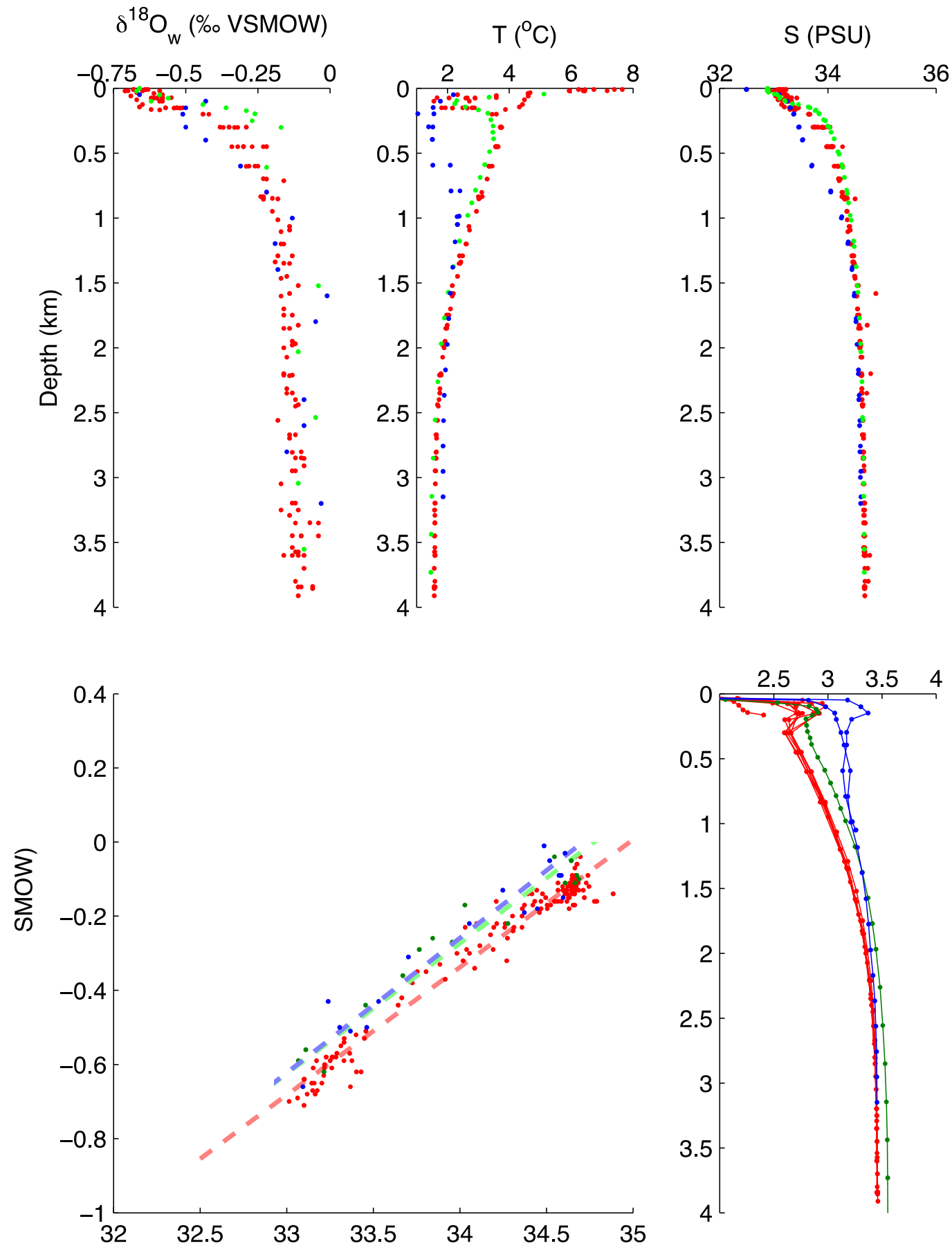

637

638

639

640

641

642
Figure 2: Hydrocast data from the Bering Sea (red), Okhotsk Sea (blue) and Emperor Seamounts (green). (a, d) The $\delta^{18} \mathrm{O}$ of seawater $\left(\delta^{18} \mathrm{O}_{\mathrm{w}}\right)$ and salinity (S) from the hydrocasts from Figure 1 , (b, c) CTD temperature (T) and S. (e) Equilibrium calcite $\delta^{18} \mathrm{O}\left(\delta^{18} \mathrm{O}_{\mathrm{c}}\right)$ calculated from the T and $\mathrm{S}$ in panels b and c, and the $\delta^{18} \mathrm{O}_{\mathrm{w}}$-S relationship in panel d, using Equation 1 (Shackleton, 1974). 

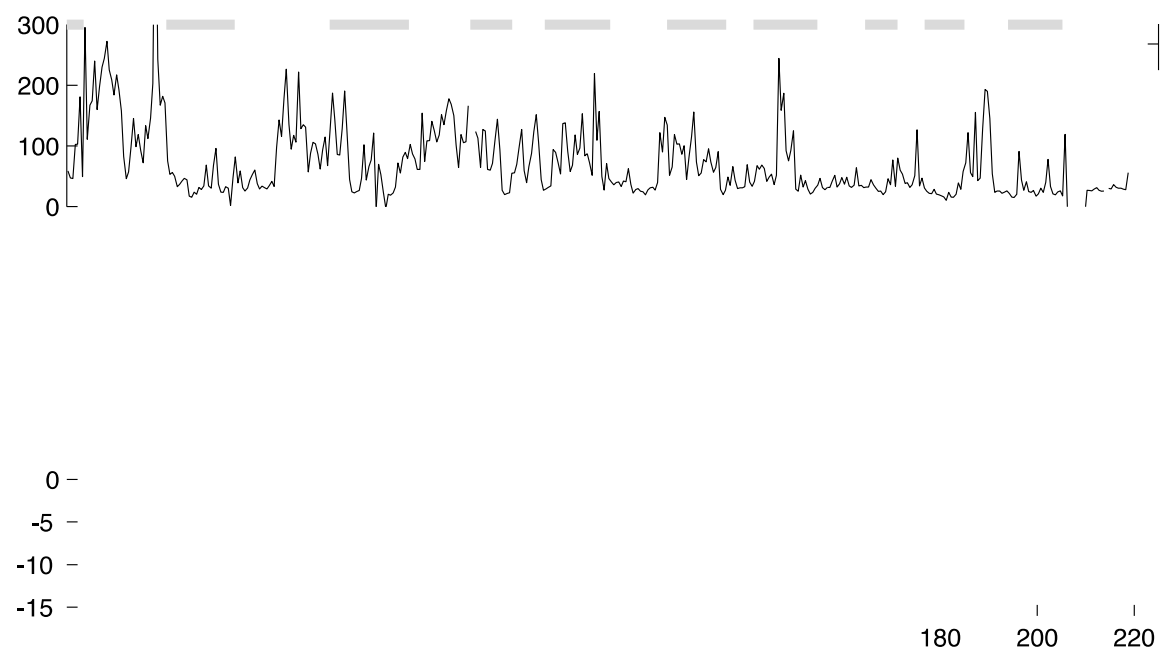

644 Figure 3: Benthic stable isotope stratigraphy of U1339 and U1345 based on U. peregrina (black), 645 U. senticosa (green), N. labradorica (blue), G. affinis (red) and E. batialis (orange). (a, e)

646 Gamma-ray attenuation bulk density, binned at $0.5 \mathrm{~m}$ resolution. (b, f) Magnetic susceptibility, 647 binned at $0.5 \mathrm{~m}$ resolution. (c, g) Composite $\delta^{18} \mathrm{O}$, using the species offset correction from Table 648 1. The heavy grey line goes through the average value for each sample. $(\mathrm{d}, \mathrm{h})$ The benthic $\delta^{13} \mathrm{C}$. 649 The thin black line connects the $U$. peregrina data. In panels c, d, g and h, open circles show 650 Uvigerina with $\delta^{13} \mathrm{C}<-2.5 \%$, the isotope data from these samples are not used in calculating 651 species offsets or in the stable isotope stratigraphy. Interglacials according to the age model in 652 Table 2 are shaded in grey. 
653
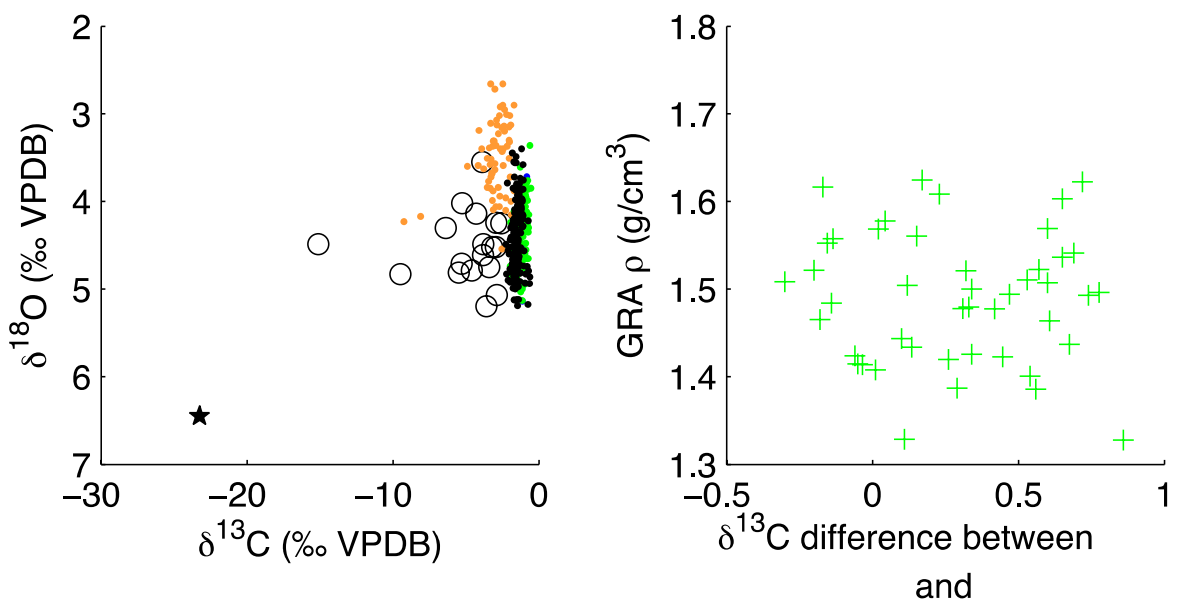

Figure 4: Assessment of stable isotope data from U1339 (a) Stable isotope measurements. The colors and markers are the same as in Figure 3, where the $U$. peregrina with $\delta^{13} \mathrm{C}<-2.5 \%$ are marked with open circles. These filtered data fall roughly in the region of the $\delta^{18} \mathrm{O}-\delta^{13} \mathrm{C}$ plot of mixing between foraminiferal calcite and the composition of authigenic carbonate estimated by Cook et al. (2011) for the Umnak region during MIS3 (star). (b) Comparison of the $\delta^{13} \mathrm{C}$ difference between $U$. senticosa and $U$. peregrina and the bulk density, which is a proxy for productivity. There does not appear to be a relationship between productivity and $\delta^{13} \mathrm{C}$ difference. 

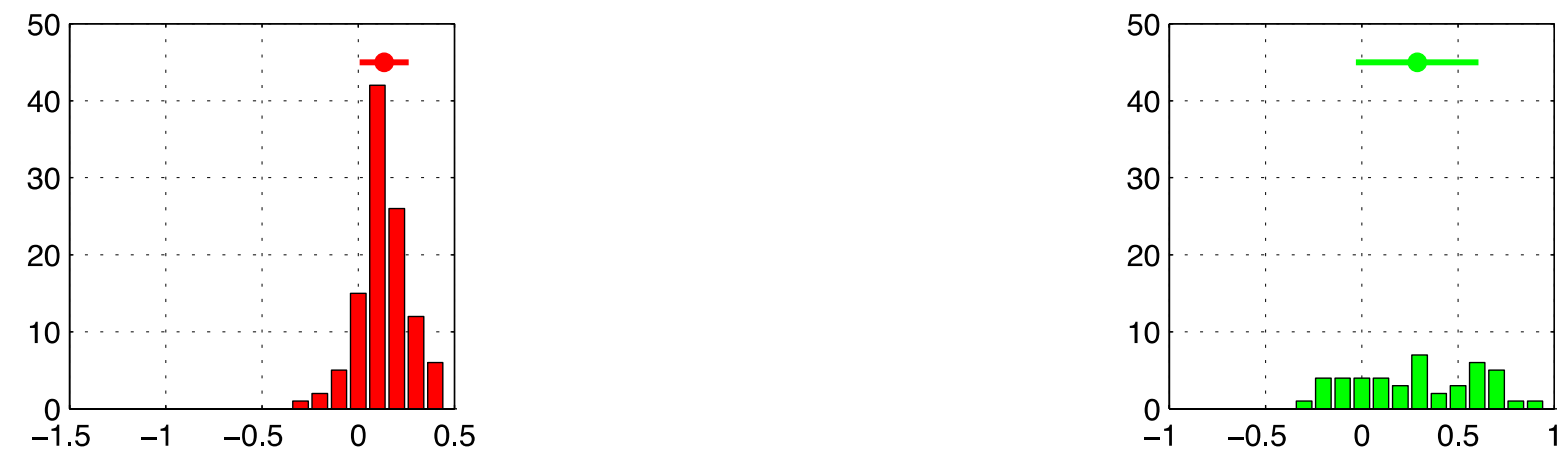

663 Figure 5: The offset between $U$. peregrina and other benthic species in samples where multiple 664 species were measured in U1345 and U1339. The mean and standard deviation of the offset for 665 each species (Table 1) are shown in the heavy lines. The colors are the same as in Figure 3.

666 


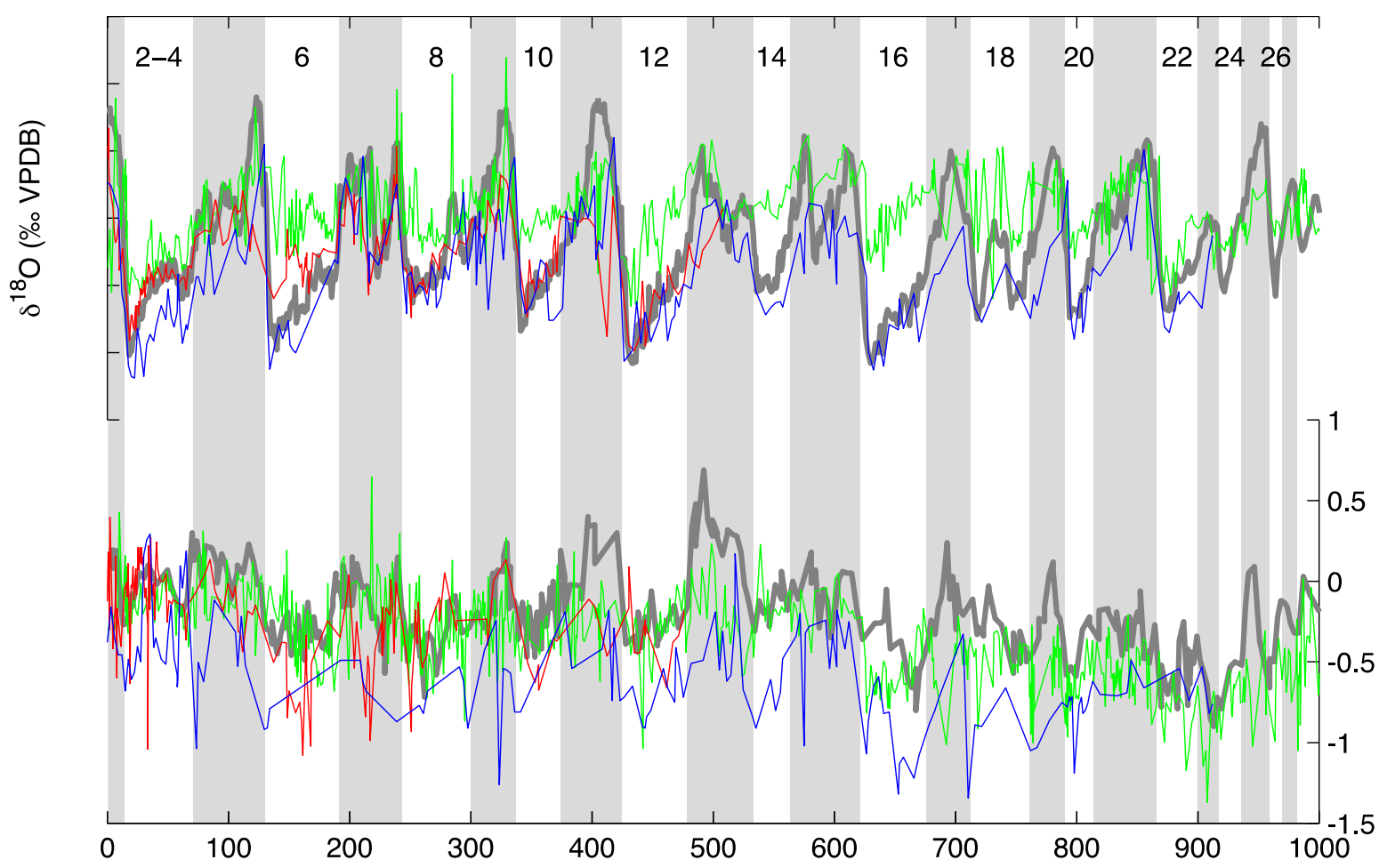

667

668 Figure 6: Stable isotope records from the Bering Sea (U1345, red; U1339, blue; U1342, green) compared to the global benthic $\delta^{18} \mathrm{O}$ stack (Lisiecki and Raymo, 2005) in grey in the top panel 671 in the lower panel. The interglacials (Lisieick and Raymo, 2005) are shaded in grey. The U1342 672 data are from Knudson and Ravelo (in review). We correct the Uvigerina $\delta^{13} \mathrm{C}$ data by $+0.9 \%$ 673 (Mix, 1995).

674 
675

676

677

678

679

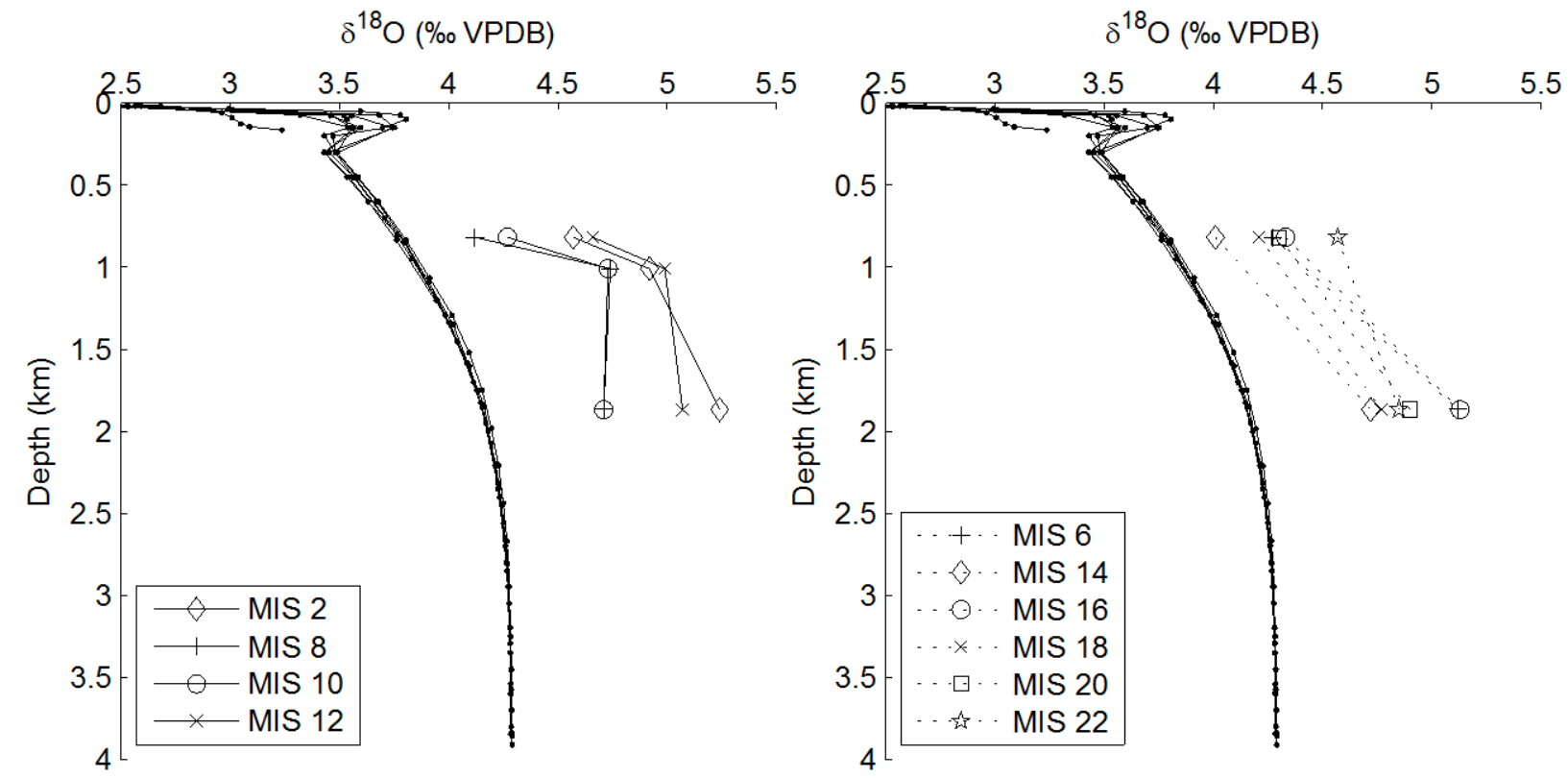

Figure 7: Bering Sea $\delta^{18} \mathrm{O}_{\mathrm{c}}$ (Figure 2) adjusted by $+1.1 \%$ for the whole-ocean change since the LGM (Labeyrie et al., 2002) compared to maximum glacial $\delta^{18} \mathrm{O}$ (Table 4). (Left) Glacial profiles from U1342 (819 m), U1345 (1008 m) and U1339 (1868 m). (Right) Glacial profiles from U1342 and U1339. 


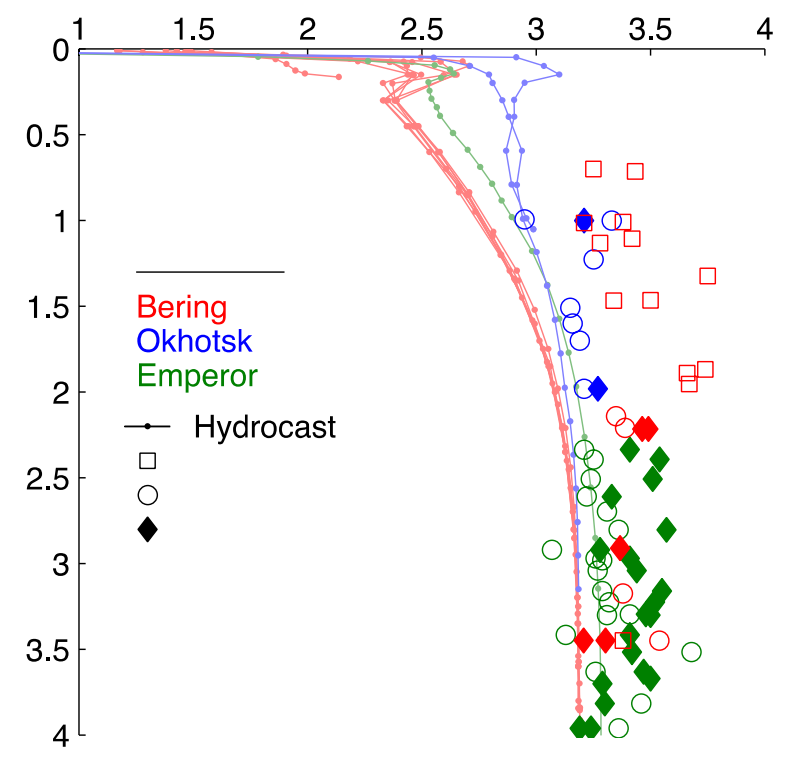

682 Figure 8: Holocene and LGM profiles from the Bering Sea (Table 3), Okhotsk Sea and Emperor 683 Seamounts (Keigwin, 1998). The Cibicioides have been corrected by $+0.5 \%$ in for offset of $\delta^{18} \mathrm{O}$ 684 from equilibrium (Fontanier et al., 2006). The $U$. senticosa have been corrected for $\delta^{13} \mathrm{C}$ offset 685 from $U$. peregrina (Table 1 and Figure 5). We correct the Uvigerina $\delta^{13} \mathrm{C}$ data by $+0.9 \%$ (Mix, 1995). (a) The equilibrium calcite $\delta^{18} \mathrm{O}\left(\delta^{18} \mathrm{O}_{\mathrm{c}}\right.$ corrected to VPDB) from Figure 2e plotted with Holocene benthic foraminiferal $\delta^{18} \mathrm{O}$. (b) The $\delta^{13} \mathrm{C}_{\text {DIC }}$ from hydrocasts (Figure 1) plotted with Holocene benthic foraminiferal $\delta^{13} \mathrm{C}$. (c) The $\delta^{18} \mathrm{O}_{\mathrm{c}}$ adjusted by $+1.1 \%$ for the whole-ocean change since the LGM (Labeyrie et al., 2002), plotted with the benthic foraminiferal maximum $\delta^{18} \mathrm{O}$ from the LGM. (d) The $\delta^{13} \mathrm{C}_{\mathrm{DIC}}$ adjusted by $-0.32 \%$ for the whole ocean change since the LGM (Duplessey et al., 1988), plotted LGM benthic foraminiferal $\delta^{13} \mathrm{C}$. 

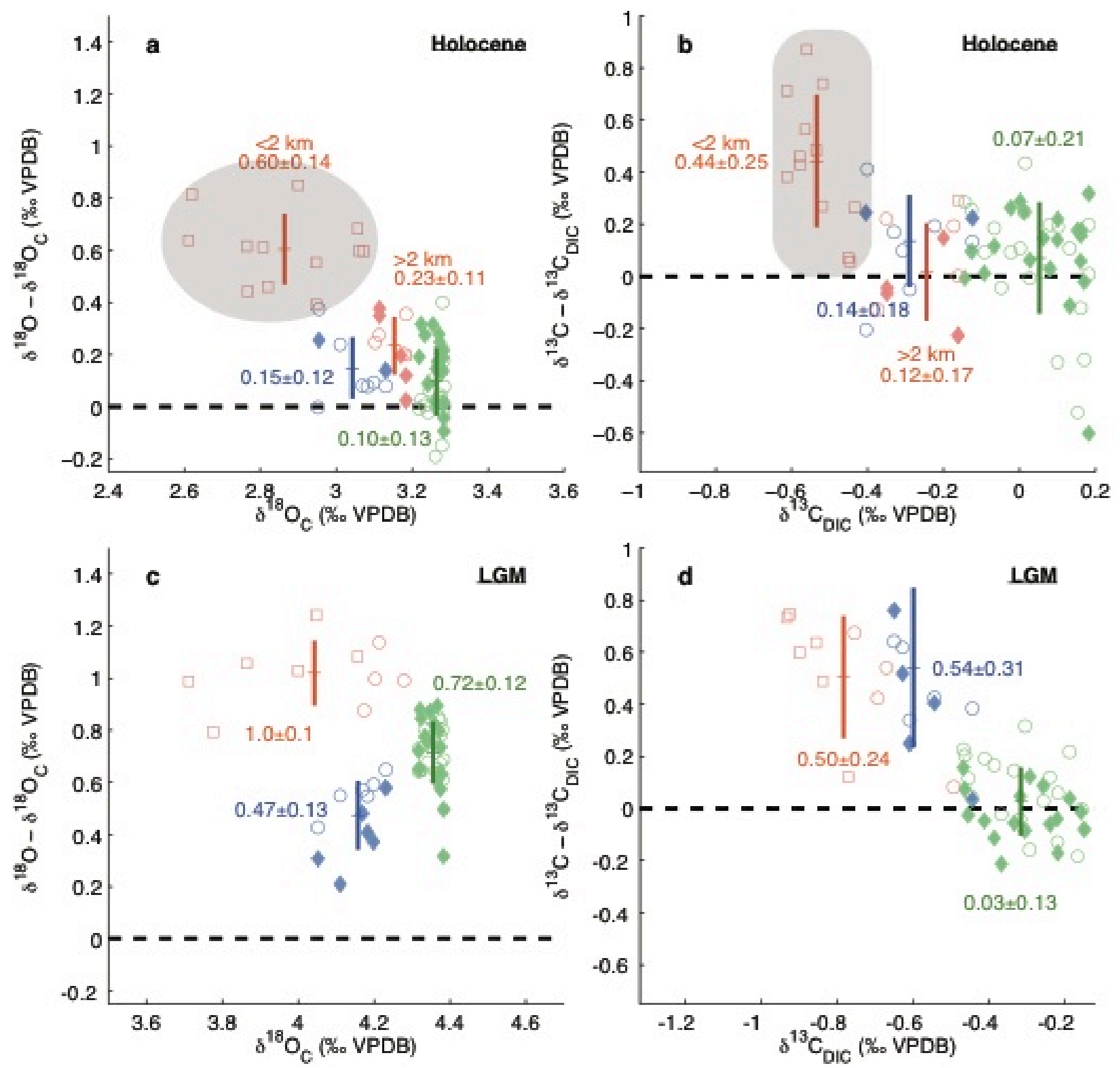

692

693

694

695

696

697

698

699

700

701
Figure 9: Benthic foraminiferal stable isotope offsets from the hydrographic reference curves. Each symbol shows the difference between a stable isotope measurement in Figure 8 (including any associated species offset) and the mean value of the hydrocast reference curves for that water depth (for panels c and d, including the adjustment for the whole-ocean change since the LGM). The colors and symbols are the same as in Figure 8, and the four panels here correspond to the four panels in Figure 8. The thick lines and annotations show the mean and standard deviation of values from each study area. In panels a and b, the mean and standard deviation of Bering Sea data $<2 \mathrm{~km}$ water depth (enclosed by grey shading) are calculated separately from the data $>2$ $\mathrm{km}$ water depth. 